\title{
Welcome to Ozone Therapy
}

\section{Marianno Franzini \\ Oxygen-Ozone Therapy Scientific Society, Gorle (BG), Italy}

I'm proud and excited to announce the launch of the brand new journal Ozone Therapy, dedicated to the ozone-therapy practitioners worldwide.

The current scenario is crowded with scientific journals, however a truly competent scientific source does not yet exist on the oxygenozone therapy. This is the main reason why we decided to launch a new scientific journal, with the aim of making it the authoritative venue for the current thinking, developments and the most recent researches, and for clinical and outpatient applications.

Ozone Therapy intends to be the accessible and innovative leading edge journal for the ozone-therapy practitioners worldwide, by publishing in different languages to be easier referred to and by establishing its own source of scientific information.
Ozone Therapy seeks to publish peer-reviewed, original manuscripts dedicated to oxygen-ozone therapy; innovative observational works to open new therapeutic frontiers and study/verification scientific papers regarding known and registered applications.

I'm convinced that the ongoing researches and the progress of innovative applications will add prestige to a medical practice already described by many patients as Source of life.

I conclude by calling on all the ozone-therapy practitioners to work with us and with the scientific committee of Ozone Therapy for achieving this crucial goal.

Prof. Marianno Franzini

President of SI00T (Oxygen-Ozone Therapy Scientific Society) E-mail: info@ossigenoozono.it
Correspondence: Marianno Franzini, Oxygen-0zone Therapy Scientific Society (SIOOT), via Roma 69, 24020 Gorle (BG), Italy.

Tel.: +39.035.300903 - +39.035.2922550.

E-mail: marianno.franzini@gmail.com

Received for publication: 28 January 2016.

Accepted for publication: 24 February 2016.

(C) Copyright M. Franzini, 2016

Licensee PAGEPress, Italy

Ozone Therapy 2016; 1:5836

doi:10.4081/ozone.2016.5836

This article is distributed under the terms of the Creative Commons Attribution Noncommercial License (by-nc 4.0) which permits any noncommercial use, distribution, and reproduction in any medium, provided the original author(s) and source are credited. 